\title{
Mother and Fetal Factors with Unplanned Cesarean Section
}

\author{
$1^{\text {st }}$ Diah Andriani Kusumastuti \\ Study of Program of Bachelor of Midwifery \\ Muhammadiyah University of Kudus \\ Kudus, Indonesia \\ diahandriani@umkudus.ac.id
}

\author{
$2^{\text {nd }}$ Anis Solikah \\ Health Faculty \\ Muhammadiyah University of Kudus \\ Kudus, Indonesia \\ anissolikah@umkudus.ac.id
}

\author{
$3^{\text {rd }}$ Umi Khobibatun Muniroh \\ Study of Program of Bachelor of Nursery \\ Muhammadiyah University of Kudus \\ Kudus, Indonesia \\ umikhobibatun@gmail.co.id
}

\begin{abstract}
The prevalence of cesarean delivery in Asia from 1990-2014 has increased by $19.2 \%$. This study aims to determine the relationship between maternal and fetal factors with the action section cesarean at Permata Bunda Hospital, Purwodadi-Grobogan. Specifically: 1) describe the characteristics of respondents in cesarean section based on age, parity, maternal indications and fetal indications, 2) to describe the relationship between maternal parity to cesarean section, 3) to describe the relationship between mother's parity to cesarean section, 4) to describe the relationship between mother's relative-absolute indications of cesarean section, 5) describes the relationship between fetal relativeabsolute indications of cesarean section action. Methods: Research is correlational descriptive with cross-sectional time. The study population was 123 people in 2016 . The samples were selected by simple random sampling of 55 respondents. Based on the inclusion criteria: minimum junior high school or equivalent, interval birth 2 to 5 years. Exclusion Criteria: repeated $\mathrm{SC}$ without indication $\mathrm{CPD}, \mathrm{SC}$ own request. The study used secondary data from medical record of Permata Bunda Hospital, Purwodadi-Grobogan, ie age, parity, mother's indication, fetal indication and cesarean. Data Analysis used Chi-Square and continued with Odds Ratio. Conclusion: 1) There is a correlation between mother age variable to cesarean section, bivariate test of chi square of $95 \%$ confidence level, $p$ value $0,02<0,05$. Odds Ratio 0.28 , 95\% CI and limit 0.078-0.746. 2) There is a correlation between parity of mother to cesarean section, chi square test confidence level $95 \%$, p value $0,01<0,05$. Odds Ratio 0.24, 95\% CI and limit $\mathbf{0 . 0 0 9 3 - 0 . 8 7 4 . 3 )}$ There is a correlation between mother's relative-absolute indication to cesarean section, chi square test of $95 \%$ confidence level, $p$ value 0,000 $<0,05$. Odds Ratio) $0.24,95 \%$ CI and limit 0.1-0.256. 4) There is a correlation between fetal's relative-absolute indication to cesarean section, chi square test of $95 \%$ confidence level, $p$ value $0,002<0,05$. Odds Ratio $0.16,95 \%$ CI and $0.05-0.553$ limit.
\end{abstract}

\section{Keywords-mother, fetal, cesarean section}

\section{INTRODUCTION}

Giving a birth with normally is the most women's dream in her life in the whole world. Unfortunately, not those things could be reached because so many factor that influence in pregnancy and also when a mother giving a birth. It could be come from mother factor or the fetus. Mother detah number in the Center of Java in 2016 has been decreased than before. When 2015 there are 619 cases, and then 2016 has been decreased became 602 cases. Based on the 2015 MDGs (Millennium Development Goals) agreement, it is expected that the maternal mortality rate will decrease to 102 per 100,000 live births. Some of the death factors are caused by the risk of being late (three late), including being late in pregnancy checkups in obtaining delivery services from health workers, and being late in getting to a health facility due to an emergency[1]

In labor is an act of artificial childbirth, one of the acts is section cesarean delivery (SC). According to Berghella [2], section cesarean delivery is an artificial labor that gives birth to an abdominal fetus with laparotomy. History of SC has been known since ancient Hindu times, Egypt, Greece, Rome and several other European traditions [3]. According to Gjonej et al (2014), section cesarean has experienced an increase throughout Latin America, found at $43.6 \%$ in government health services and $80 \%$ in private clinics [3]. While in Albania in 2011-2013 it increased from 31\% to $33 \%$. Cesarean section births in the world population increased from $10 \%$ to $15 \%$ from the beginning of 1985 to 2014. These actions can reduce maternal, fetal and infant mortality. Although not directly related to the reduction in the prevalence of maternal mortality by $30 \%$ worldwide [2]. The prevalence of cesarean section births in Asia from 1990-2014 increased by $19.2 \%$ according to the World Health Organization Research Development in the Human Reproduction field [3].

Some obstetricians emphasize the risks associated with vaginal delivery and the risk of asphyxia to justify the liberal use of cesarean section[3]. A woman who has undergone SC surgery will get a disability and scar in the uterus that can endanger pregnancy and subsequent delivery, even if the danger is relatively small. An increase in infectious complications was also found to be 20 times greater than for those who delivered vaginally [4]. The risk of perinatal death in children born with The unplanned prevalence of SC from December 2016 to March 2017 was based on maternal factors of $70.8 \%$ (56 people) and fetal factors $29.1 \%$ (23 people). SC actions are planned based on maternal factors $55.6 \%$ (44 people) and fetal factors $44.3 \%$ (35 people).Initial observation data from the Medical Record of Permata Bunda Hospital November 2016January 2017 on 31 clients who received SC actions because of Heavy Pre Eklampsi 8 people, premature rupture of membranes 6 people, Cephalo Pelvic 
Disproportion 3 people, long labor 3 people, amused 1 person, fetal distress 1 person, hidrocefalus 1 person, at his own request 7 people. Based on these data, we want to conduct a study that examines the relationship between maternal and fetal factors against cesarean section.

\section{LITERATURE STUDY AND HYPOTHESIS DEVELOPMENT}

A. Severe preeclampsia (PEB)

1) Definition

Pregnancy is the period from the start of conception until the birth of the fetus. The duration of normal pregnancy is 280 days (40 weeks or 9 months 7 days) calculated from the first day of the last menstrual period. Pregnancy in the third quarter is between 28 - 40 weeks. Preeclampsia is an increase in blood pressure that appears after a gestational age of more than 20 weeks marked by the results of laboratory tests containing urine protein and rapid weight gain because the body experiences edema or swelling [6]. Severe preeclampsia is a pregnancy complication characterized by the onset of hypertension $160 / 110 \mathrm{mmHg}$ or more accompanied by proteinuria and / or edema in pregnancies of 20 weeks or more[4]. Meanwhile, severe preeclampsia is a disease with typical signs such as high blood pressure (hypertension), tissue swelling (edema), and the discovery of protein in the urine (proteinuria) arising from pregnancy. This disease generally occurs in the 3rd trimester of pregnancy, but can also occur in the second trimester of pregnancy. Severe prereclamation is followed by the onset of hypertension accompanied by urinary protein and edema due to pregnancy after 20 weeks' gestation or immediately after delivery [9]. So it can be concluded that severe preeclampsia is a complication that occurs during pregnancy with a characteristic that is accompanied by hypertension $\geq 160 / 110 \mathrm{mmHg}$ and or accompanied by positive urine protein 2 and or 3 and commonly accompanied by edema in pregnancy kehamilan20 weeks. Researcher will analyze the relationship of parity, pregnancy history, and calcium intake with the incidence of severe pre-eclampsia at Permata Bunda Hospital.

\section{2) Type of Research}

This research is descriptive correlational. Research method aimed at describing the phenomena that exist, which took place at the present time or in the past. Descriptive research can be used a quantitative approach in the form of data collection and measurement in the form of numbers. If this research is equipped with a correlational hypothesis, it examines the relationship between related variables [7]

Techniques in pointing an abstract word and not manifested in objects, but can only be seen its use through: questionnaires, interviews, observations, tests (tests), documentation, and others. Researchers can use one or a combination of techniques depending on the problem faced or researched [8].

\section{3) Research Population}

Population is a generalization area that consists of objects / subjects that have certain qualities and characteristics determined by researchers to be studied and then conclusions are drawn [6]. The population in this study were all women who received SC in Permata Bunda Hospital, Purwodadi-Grobogan during 2016 (JanuaryDecember) as many as 1469 people.

4) Samples

The sample is part of the number and characteristics possessed by the population. If the population is large, and researchers may not study everything in the population, for example due to limited funds, manpower and time, then researchers can use samples taken from that population. What is learned from the sample, the conclusion can be applied to the population. For this reason, samples taken from the population must be truly representative [7].

Screening of samples is done with inclusion and exclusion criteria to make the sample conditions more homogeneous. The inclusion criterion is the determination of a sample based on the general characteristics of the research subjects of an affordable target population to be studied. Exclusion criteria are criteria to eliminate / exclude subjects who meet the inclusion criteria from studies by various causes [8].

Inclusion Criteria:

a. Minimum education of junior high school or equivalent

b. Distance Between Births 2 to 5 years

Exclusion Criteria:

a. SC reset without $\mathrm{CPD}$ indication b. SC requests themselves

c. History of comorbidities before pregnancy

The minimum sample size is not different in each month. The accuracy or accuracy of the sample proportion is determined by the level of sample precision determined by the researcher by $10 \%$. The sample size uses a formula for populations less than 10,000 . The sample population of 1469 was averaged for 12 months getting 123 respondents. The large sample formula used according to Notoatmodjo [9]. :

The sampling technique in this study uses simple random sampling, which is a random determination technique with relatively homogeneous population conditions). The total sample used for this study was 55 respondents

\section{B. Characteristics of Respondents} 1) Age

Tabel 1. Frequency distribution of respondents by age mothers sc at permata bunda hospital

\begin{tabular}{|c|c|c|}
\hline Age & Total & Percentage (\%) \\
\hline $20-35 \mathrm{Th}$ & 31 & 56,4 \\
\hline$>35 \mathrm{Th}$ & 24 & 43,6 \\
\hline & & 100 \\
\hline Total & 55 & \\
\hline
\end{tabular}

The average age of mothers who perform Cesarean Section in Permata Bunda Hospital, Purwodadi-Grobogan is 33.7 years old. The minimum age is 20 years and the maximum age is 43 years. Respondents aged $20-35$ years were $56.4 \%$ (31 people). While those aged $>35$ years are $43.6 \%$ (24). 


\section{2) Mother Parity}

Table 2. Frequency distribution of respondents based on parity of sc ladies at permata bunda hospital

\begin{tabular}{|c|c|c|}
\hline Parity & Total & Percentage $(\%)$ \\
\hline $1-3$ & 30 & 54,5 \\
\hline$>3$ & 25 & 45,5 \\
\hline Total & 55 & 100 \\
\hline
\end{tabular}

Most of the respondents in this study had a parity of 1-3, 30 people or $54.55 \%$.

\section{Mother Indication}

Table 3. Frequency distribution of respondents based on indications of mother sc at permata bunda hospital

\begin{tabular}{|c|c|c|}
\hline Indication & total & Percentage (\%) \\
\hline Relatively & 21 & 38,2 \\
\hline Absolute & 34 & 61,8 \\
\hline Total & 55 & 100 \\
\hline
\end{tabular}

The biggest indication for mothers in the study sample is absolute, 34 people or $61.88 \%$

\section{Fetus Indication}

Table 4. Frequency distribution of respondents based on fetus indications at permata bunda hospital

\begin{tabular}{|c|c|c|}
\hline Indication & Total & Percentage (\%) \\
\hline Relatively & 34 & 61,8 \\
\hline Absolute & 21 & 38,2 \\
\hline Total & 55 & 100 \\
\hline
\end{tabular}

The biggest fetal indication in the study sample was relative, 34 people or $61.8 \%$.

Table 5. Distribution of respondent frequencies based on section cesarean measures in permata bunda hospital

\begin{tabular}{|c|c|c|}
\hline $\begin{array}{c}\text { Section } \\
\text { caesarea }\end{array}$ & Jumlah & Prosentase (\%) \\
\hline Unplanned & 25 & 45,45 \\
\hline By Plan & 30 & 54,55 \\
\hline Total & 55 & 100 \\
\hline
\end{tabular}

The largest cesarean section in the study sample was planned, 30 people or $54.55 \%$.

\section{RESULTS AND DISCUSSION}

\section{A. Bivariate Analysis}

Table 6. Frequency distribution of respondents according to age and section caesarea

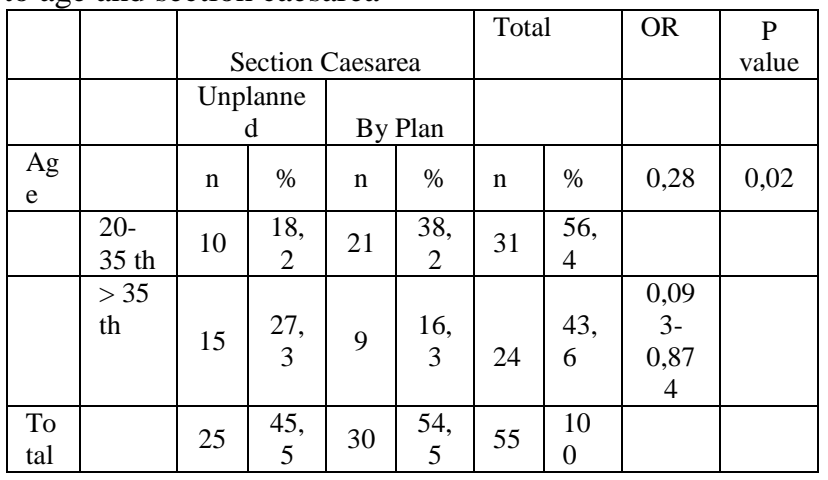

Based on chi square analysis at $95 \%$ confidence level of table data 6 that maternal age is related to Cesarean Section action associated with $\mathrm{p}$ value $0.02<0.05$. Odds Ratio value of 0.28 with a confidence interval (CI) of $95 \%$ and a limit of 0.0093-0.874.

Table 7. Frequency distribution of respondents according to parity and section cesarean measures

\begin{tabular}{|c|c|c|c|c|c|c|c|c|c|}
\hline & & \multicolumn{3}{|c|}{ Section Caesarea } & \multicolumn{2}{|c|}{ Total } & OR & $\begin{array}{c}\text { P } \\
\text { value }\end{array}$ \\
\hline & & Unplanned & \multicolumn{2}{|c|}{ By Plan } & & & $\begin{array}{c}\text { CI } \\
95 \%\end{array}$ & \\
\hline Parity & & $\mathrm{n}$ & $\%$ & $\mathrm{n}$ & $\%$ & $\mathrm{n}$ & $\%$ & 0,24 & 0,01 \\
\hline & $1-$ & 9 & 16,4 & 21 & 38,2 & 30 & 54,5 & & \\
\hline & $>$ & 16 & 29,1 & 9 & 16,4 & 25 & 45,5 & $\begin{array}{c}0,078- \\
0,746\end{array}$ & \\
\hline & 3 & 16 & 45,5 & & 54,5 & 55 & 100 & & \\
\hline Total & & & 45,5 &
\end{tabular}

Based on the chi square analysis at the $95 \%$ confidence level of table data 7 that parity is related to the Section Caesarea action associated with a $\mathrm{p}$ value of $0.01<0.05$. Odds Ratio value is 0.24 with a confidence interval (CI) of $95 \%$ and a limit of $0.078-0.746$.

Table 8. Frequency distribution of respondents according to maternal indications and section cesarean measures

\begin{tabular}{|c|c|c|c|c|c|c|c|c|c|}
\hline & & \multicolumn{4}{|c|}{ Section Caesarea } & \multicolumn{2}{|c|}{ Total } & \multirow[b]{2}{*}{$\begin{array}{l}\text { OR } \\
\text { CI } \\
95 \\
\%\end{array}$} & \multirow[t]{2}{*}{$\begin{array}{c}\mathrm{P} \\
\text { val } \\
\text { ue }\end{array}$} \\
\hline & & \multicolumn{2}{|c|}{$\begin{array}{l}\text { Unplann } \\
\text { ed }\end{array}$} & \multicolumn{2}{|c|}{ By Plan } & & & & \\
\hline \multirow[t]{3}{*}{$\begin{array}{l}\text { mother } \\
\text { Indicat } \\
\text { ion }\end{array}$} & & $\mathrm{n}$ & $\%$ & $\mathrm{n}$ & $\%$ & $\mathrm{n}$ & $\%$ & $\begin{array}{l}0,0 \\
5\end{array}$ & $\begin{array}{c}0,0 \\
00\end{array}$ \\
\hline & $\begin{array}{l}\text { Relativ } \\
\text { ely }\end{array}$ & 2 & 3,6 & $\begin{array}{l}1 \\
9 \\
\end{array}$ & $\begin{array}{c}34, \\
5\end{array}$ & $\begin{array}{l}2 \\
1 \\
\end{array}$ & $\begin{array}{l}38, \\
2 \\
\end{array}$ & & \\
\hline & $\begin{array}{l}\text { absolut } \\
\text { ely }\end{array}$ & $\begin{array}{l}2 \\
3\end{array}$ & $\begin{array}{c}41, \\
8\end{array}$ & $\begin{array}{l}1 \\
1\end{array}$ & 20 & $\begin{array}{l}3 \\
4\end{array}$ & $\begin{array}{l}61, \\
8\end{array}$ & $\begin{array}{l}0,1- \\
0,2 \\
56\end{array}$ & \\
\hline Total & & & $\begin{array}{c}45, \\
5\end{array}$ & & $\begin{array}{c}54, \\
5\end{array}$ & $\begin{array}{l}5 \\
5\end{array}$ & $\begin{array}{l}10 \\
0\end{array}$ & & \\
\hline
\end{tabular}

Based on chi square analysis at $95 \%$ confidence level of table data 8 that maternal indications are related to Cesarean Section related to $p$ value $0,000<0.05$. Odds Ratio value of 0.05 with a confidence interval (CI) of $95 \%$ and a limit of $0.1-0.256$.

Table 9. Frequency distribution of respondents according to fetal indications and section cesarean measures

\begin{tabular}{|c|c|c|c|c|c|c|c|c|c|}
\hline & & \multicolumn{4}{|c|}{ Section Caesarea } & \multicolumn{2}{|c|}{ Total } & \multirow[b]{2}{*}{$\begin{array}{l}\text { OR } \\
\text { CI } \\
95 \\
\%\end{array}$} & \multirow[t]{2}{*}{$\begin{array}{c}\mathrm{P} \\
\text { val } \\
\text { ue }\end{array}$} \\
\hline & & \multicolumn{2}{|c|}{$\begin{array}{l}\text { Unplann } \\
\text { ed }\end{array}$} & \multicolumn{2}{|c|}{ By Plan } & & & & \\
\hline \multirow[t]{3}{*}{$\begin{array}{l}\text { Fetus } \\
\text { Indicat } \\
\text { ion }\end{array}$} & & $\mathrm{n}$ & $\%$ & $\mathrm{n}$ & $\%$ & $\mathrm{~N}$ & $\%$ & $\begin{array}{c}0,1 \\
6\end{array}$ & $\begin{array}{l}0,0 \\
02\end{array}$ \\
\hline & $\begin{array}{l}\text { Relativ } \\
\text { ely }\end{array}$ & $\begin{array}{l}1 \\
0\end{array}$ & $\begin{array}{c}18, \\
2\end{array}$ & $\begin{array}{l}2 \\
4\end{array}$ & $\begin{array}{c}43, \\
6\end{array}$ & $\begin{array}{l}3 \\
4\end{array}$ & $\begin{array}{l}61, \\
8\end{array}$ & & \\
\hline & $\begin{array}{l}\text { Absolu } \\
\text { te }\end{array}$ & $\begin{array}{l}1 \\
5\end{array}$ & $\begin{array}{c}27, \\
3\end{array}$ & 6 & $\begin{array}{c}10, \\
9\end{array}$ & $\begin{array}{l}2 \\
1\end{array}$ & $\begin{array}{l}38, \\
2\end{array}$ & $\begin{array}{c}0,0 \\
5- \\
0,5 \\
53\end{array}$ & \\
\hline Total & & & $\begin{array}{c}45, \\
5\end{array}$ & & $\begin{array}{c}54, \\
5\end{array}$ & $\begin{array}{l}5 \\
5\end{array}$ & $\begin{array}{l}10 \\
0\end{array}$ & & \\
\hline
\end{tabular}


Based on the chi square analysis at the $95 \%$ confidence level in table 9 that fetal indications are related to the Cesarean Sectional action associated with $\mathrm{p}$ values of 0.002 $<0.05$. Odds Ratio value is 0.16 with a confidence interval (CI) of $95 \%$ and a limit of $0.05-0.553$.

\section{CONCLUSION}

Conclusion: 1) There is a correlation between mother age variable to cesarean section, bivariate test of chi square of $95 \%$ confidence level, $\mathrm{p}$ value $0,02<0,05$. Odds Ratio 0.28 , 95\% CI and limit 0.078-0.746. 2) There is a correlation between parity of mother to cesarean section, chi square test confidence level 95\%, p value 0,01<0,05. Odds Ratio 0.24, 95\% CI and limit 0.0093-0.874.3) There is a correlation between mother's relative-absolute indication to cesarean section, chi square test of $95 \%$ confidence level, $p$ value $0,000<0,05$. Odds Ratio) $0.24,95 \%$ CI and limit 0.1-0.256. 4) There is a correlation between fetal's relative-absolute indication to cesarean section, chi square test of $95 \%$ confidence level, p value $0,002<0,05$. Odds Ratio 0.16 , 95\% CI and 0.05-0.553 limit.

\section{REFERENCES}

[1] Reeder, "Analisa Indikasi Dilakukan Persalinan Section Caesarean Di RSUP Dr. Soeradji Tirtonegoro Klaten," Univ. Muhammadiyah
Surakarta, 2013.

[2] N. Degani and N. Sikich, "Caesarean delivery rate review: An evidence-based analysis," Ont. Health Technol. Assess. Ser., vol. 15, no. 9, pp. 1-58, 2015.

[3] A. P. Betrán, J. Ye, A. B. Moller, J. Zhang, A. M. Gülmezoglu, and M. R. Torloni, "The increasing trend in caesarean section rates: Global, regional and national estimates: 1990-2014," PLoS One, vol. 11 , no. 2, pp. 1-12, 2016

[4] S. Soltanifar and R. Russell, "The National Institute for Health and Clinical Excellence (NICE) guidelines for caesarean section, 2011 update: Implications for the anaesthetist," Int. J. Obstet. Anesth., vol. 21, no. 3, pp. 264-272, 2012.

[5] T. Kulas, D. Bursac, Z. Zegarac, G. Planinic-Rados, and Z. Hrgovic, "New Views on Caesarean Section, its Possible Complications and Long-Term Consequences for Children's Health,” Med. Arch. (Sarajevo, Bosnia Herzegovina), vol. 67, no. 6, pp. 460-463, 2013.

[6] M. R. Festin et al., "Caesarean section in four South East Asian countries: Reasons for, rates, associated care practices and health outcomes," BMC Pregnancy Childbirth, vol. 9, 2009.

[7] Y. Dibaba, "Child Spacing and Fertility Planning Behavior among Women in Mana District, Jimma Zone, South West Ethiopia," Ethiop. J. Health Sci., vol. 20, no. 2, 2011.

[8] N. Genuttis, M. Bolz, and V. Briese, "Can the Rate of C-sections Performed in a Level i Perinatal Center Be Reduced? - An Analysis of the University Gynecology Clinic Rostock, 2008-2014," Geburtshilfe Frauenheilkd., vol. 77, no. 7, pp. 771-779, 2017.

[9] K. Cunningham, F., Levono, k., Bloom, S., Hauth, J., Gilstrap, L., \& Wenstrom, "Williams_Obstetrics_-22_Edition_20050071413154-Mcgraw-Hill_Professional.” 2005.

[10] Notoatmodjo , S. 2005. Metodologi Penelitian Kesehatan. Jakarta: Rineka Cipta 